Pesq. Vet. Bras. 38(3):387-392, março 2018

\title{
Detection and genetic identification of pestiviruses in Brazilian lots of fetal bovine serum collected from 2006 to $2014^{1}$
}

\author{
Francielle L. Monteiro², Juliana F. Cargnelutti², Patrícia Braunig², \\ Aurea V. Folgueras-Flatschart ${ }^{3}$, Nathália C. Santos ${ }^{3}$, \\ Edviges M. Pituco ${ }^{4}$, Rudi Weiblen ${ }^{2}$ and Eduardo F. Flores ${ }^{2 *}$
}

\begin{abstract}
Monteiro F.L., Cargnelutti J.F., Braunig P., Folgueras-Flatschart A.V., Santos N.C, Pituco E.M., Weiblen R. \& Flores E.F. 2018. Detection and genetic identification of pestiviruses in Brazilian lots of fetal bovine serum collected from 2006 to 2014. Pesquisa Veterinária Brasileira 38(3):387-392. Setor de Virologia, Universidade Federal de Santa Maria, Prédio 63A, Parque de Exposições, Universidade Federal de Santa Maria, Avenida Roraima 1000, Santa Maria, RS 97105-900, Brazil. E-mail: eduardofurtadoflores@gmail.com

The present study performed a genetic identification of pestiviruses contaminating batches of fetal bovine serum (FBS) produced in Brazil from 2006 to 2014. Seventy-three FBS lots were screened by a RT-PCR targeting the 5'untranslated region (UTR) of the pestivirus genome. Thirty-nine lots $(53.4 \%)$ were positive for pestivirus RNA and one contained infectious virus. Nucleotide sequencing and phylogenetic analysis of the 5'UTR revealed 34 lots (46.6\%) containing RNA of bovine viral diarrhea virus type 1 (BVDV-1), being 23 BVDV-1a (5' UTR identity 90.8-98.7\%), eight BVDV-1b (93.9-96.7\%) and three BVDV-1d (96.2- 97.6\%). Six lots (8.2\%) contained BVDV-2 (90.3-100\% UTR identity) being two BVDV-2a; three BVDV-2b and one undetermined. Four FBS batches $(5.5 \%)$ were found contaminated with HoBi-like virus (98.3 to 100\%). Five batches (6.8\%) contained more than one pestivirus. The high frequency of contamination of FBS with pestivirus RNA reinforce the need for systematic and updated guidelines for monitoring this product to reduce the risk of contamination of biologicals and introduction of contaminating agents into free areas.

INDEX TERMS: Genetic identification, pestiviruses, fetal bovine serum, BVDV, pestivirus, contamination, cattle, viroses.
\end{abstract}

\begin{abstract}
RESUMO.- [Detecção e identificação genética de pestivírus em lotes brasileiros de soro fetal bovino coletado de 2006 a 2014.] No presente estudo foi realizada a identificação genética de pestivírus contaminantes de lotes de soro fetal bovino (SFB) produzidos no Brasil de

\footnotetext{
${ }^{1}$ Received on February 14, 2017.

Accept for publication on May 2, 2017.

${ }^{2}$ Setor de Virologia, Universidade Federal de Santa Maria, Av. Roraima 1000, Prédio 63A, Parque de Exposições, Santa Maria, RS 97105-900, Brazil. *Corresponding author: eduardofurtadoflores@gmail.com

${ }^{3}$ Laboratório de Bioengenharia de Tecidos (LABIO), Diretoria de Metrologia Aplicada às Ciências da Vida (DIMAV), Instituto Nacional de Metrologia, Qualidade e Tecnologia (Inmetro), Av. Nossa Senhora das Graças 50, Xerém, Duque de Caxias, RJ 25250-020, Brazil.

${ }^{4}$ Laboratório de Viroses de Bovídeos, Instituto Biológico, Av. Conselheiro Rodrigues Alves 1.252, São Paulo, SP 04014-900, Brazil.
}

2006 a 2014. Setenta e três lotes de SFB foram testados por RT-PCR para a região 5' não traduzida do genoma dos pestivírus. Trinta e nove lotes $(53,4 \%)$ foram positivos para RNA de pestivírus e um continha vírus infeccioso. 0 sequenciamento de nucleotídeos e análise filogenética da região 5'UTR revelou que 34 lotes $(46,6 \%)$ continham RNA do vírus da diarreia viral bovina tipo 1 (BVDV-1), sendo 23 BVDV-1a (identidade na 5' UTR de 90,8-98,7\%), oito BVDV-1b (93,9 a 96,7\%) e três BVDV-1d (96,2\%-97,6\%). Seis lotes $(8,2 \%)$ continham BVDV-2 $(90,3$ a $100 \%$ de identidade), sendo dois BVDV-2a, três BVDV-2b e um de subgenótipo indeterminado. Quatro lotes de SFB $(5,5 \%)$ estavam contaminados com o vírus HoBi-like $(98,3$ a $100 \%)$. Cinco lotes $(6,8 \%)$ continham mais do que um pestivírus. A alta frequência de contaminação de SFB 
com RNA de pestivírus reforça a necessidade para diretrizes sistemáticas atualizadas para a monitoração deste produto com a finalidade de reduzir a contaminação de produtos biológicos e a introdução de agentes contaminantes em áreas livres.

TERMOS DE INDEXAÇÃO: Identificação genética, pestivírus, soro fetal bovino, BVDV, contaminação, bovinos, viroses.

\section{INTRODUCTION}

Contamination of fetal bovine serum (FBS) with bovine pestiviruses, namely bovine viral diarrhea virus (BVDV), has been a long time concern for the industry of biologicals. FBS is a major growth supplement for mammalian cell cultures and is a component of many biologicals of human and veterinary use, including vaccines. In addition, FBS has broad/wide applications in many areas of research and development. Moreover, international trade of FBS represents a potential risk for the introduction of exogenous agents into free countries (Stahl et al. 2007, Bauermann et al. 2013, Xia et al. 2013). These concerns were renewed upon the identification of a novel group of pestiviruses in a batch of FBS imported from Brazil (Schirrmeier et al. 2004).

The genus Pestivirus, family Flaviviridae, comprises four recognized virus species, Bovine viral diarrhea virus 1 and 2 (BVDV-1 and BVDV-2), Border disease virus (BDV) and Classical swine fever virus (CSFV) (Liu et al. 2009). Several other putative pestivirus species wait for definitive classification, including the emerging HoBi-like virus group, also denominated atypical pestiviruses or BVDV-3 (Schirrmeier et al. 2004, Liu et al. 2009, Bauermann \& Ridpath 2015).

The ruminant pestivirus genome is a single stranded, positive sense RNA of $12.3 \mathrm{~kb}$ in length containing a long open reading frame (ORF) flanked by two untranslated regions (5' and 3' UTRs), respectively. Nucleotide sequencing and comparison of the highly conserved 5' UTR has served for pestivirus phylogeny and classification into virus species and subtypes (Ridpath et al. 1994, Becher et al. 1997, Vilcek et al. 2001, Bauermann \& Ridpath 2015).

The first member of this novel pestivirus group (isolate HoBi_D32/00) was identified in Germany contaminating FBS imported from Brazil (Schirrmeier et al. 2004). Subsequently, genetically similar viruses - and so called HoBi-like - have been repeatedly detected in commercial FBS from different sources, but mainly from South America (Stahl et al. 2007, Liu et al. 2009, Peletto et al. 2012, Giammarioli et al. 2015). In addition, HoBi-like viruses have been associated with cattle infection and disease in several countries (Cortez et al. 2006, Liu et al. 2009, Bianchi et al. 2011, Decaro et al. 2011, 2012, Mishra et al. 2014).

As Brazil is one of the major world suppliers of FBS, and pestiviruses - including HoBi-like - have been frequently detected in Brazilian lots of FBS, we performed an investigation on the presence and identity of pestiviruses present in FBS produced in the country between 2006 and 2014.

\section{MATERIALS AND METHODS}

The current study included aliquots from 73 lots of FBS produced in Brazil between 2006 and 2014. Forty-six lots consisted of pooled fetal sera collected in slaughterhouses between 2006 and 2011. These lots have been submitted to filtration and UV irradiation prior to submission to the diagnostic laboratory. The remaining samples $(n=27)$ were obtained from commercial, packed and labeled batches of FBS produced in Brazil from 2009 to 2014. Pestivirus screening included three RT-PCRs using different sets of primers targeting the $5^{\prime}$-UTR of the genome (Table 1 ).

Aliquots of $100 \mathrm{uL}$ of each FBS batch were submitted to RNA extraction using TRIzol ${ }^{\circledR}$ Reagent (Life Technologies, Carlsbad, CA), according to manufacturer's instructions. After RNA extraction, complementary DNA (cDNA) was synthesized using Super Script III Reverse Transcriptase (Life Technologies, Carlsbad, CA). Then, cDNA from each sample was submitted to three sequential PCR assays, using different sets of primers targeting the 5'UTR (Table 1). The first PCR used the panpestivirus primers HCV90-368 (Ridpath \& Bolin, 1998). The conditions were: $94^{\circ} \mathrm{C}-5 \mathrm{~min}, 35 \mathrm{cycles}$ of $94^{\circ} \mathrm{C}, 50^{\circ} \mathrm{C}, 72^{\circ} \mathrm{C}, 30 \mathrm{~s}$ each, final extension at $72^{\circ} \mathrm{C}(7 \mathrm{~min})$. The second PCR used primers specific for BVDV-2 (2F-2R), that was designed in CloneManager software (http://www.scied.com/pr_cmbas.htm) using the strain 890 as standard sequence (GenBank access U18059). The obtained primers sets were analyzed in primer-BLAST tool to specificity parameters (https://www.ncbi.nlm.nih.gov/tools/primer-blast/). Conditions were: $94^{\circ} \mathrm{C}-5 \mathrm{~min}, 35$ cycles of $94^{\circ} \mathrm{C}, 52^{\circ} \mathrm{C}$ and $72^{\circ} \mathrm{C}$ extension for $45 \mathrm{sec}$ each, final extension of $7 \mathrm{~min}-72^{\circ} \mathrm{C}$. The third PCR used primers N2-R5 targeting the HoBi-virus $5^{\prime}$ UTR (Bauermann et al. 2014). Conditions were $94^{\circ} \mathrm{C}-5 \mathrm{~min}$, 35 cycles of $94^{\circ} \mathrm{C}, 55^{\circ} \mathrm{C}$ and $72^{\circ} \mathrm{C}$ for 30 sec each, followed by an extension at $72^{\circ} \mathrm{C}-5 \mathrm{~min}$. The PCR reactions were performed in a $25 \mu \mathrm{l}$ volume, using $2 \mu \mathrm{l}$ of cDNA template (100 to $200 \mathrm{ng}$ ),

Table 1. Primer sequences and PCR amplification of pestiviruses present in Brazilian batches of fetal bovine serum (FBS) collected from 2006 to 2014

\begin{tabular}{|c|c|c|c|c|}
\hline Primers & Sequence & Amplicon & Positive (\%) & Identification \\
\hline HCV90-368 & F:CCATGTGCCATGTACAG R:CATGCCCATAGTAGGAC & $282 \mathrm{bp}$ & $35 / 73(47.9)$ & $\begin{array}{l}24 \text { BVDV-1a; } \\
8 \text { BVDV-1b; } \\
2 \text { BVDV-1d; } \\
1 \text { HoBi-like }\end{array}$ \\
\hline BVDV-2 $2 \mathrm{~F}$ and $2 \mathrm{R}$ & $\begin{array}{l}\text { F: GCGGTAGCAGTGAGTTTATTGG } \\
\text { R: TTTACTAGCGGGATAGCAGGTC }\end{array}$ & $224 \mathrm{bp}$ & $6 / 73(8.2)$ & 6 BVDV-2 \\
\hline N2-R5 & F:TCGACGCATCAAGGAATGCCT R:TAGCAGGTCTCTGCAACACCCTAT & $150 \mathrm{bp}$ & $4(5.5)$ & 4 HoBi-like \\
\hline
\end{tabular}

Five fetal bovine serum (FBS) batches contained more than one viral species: 4 were positive for BVDV-1 and BVDV- 2 ; one contained BVDV-1 and HoBilike virus; one contained BVDV-2 and HoBi-like virus. 
$0.4 \mu \mathrm{M}$ of each primer, $2 \mathrm{mM} \mathrm{MgCl}, 0.8 \mathrm{mM}$ of dNTPs, $1 \times$ reaction buffer, $10 \%$ of reaction dimetilsulfoxide (BVDV-2) and 1.5 unit of Taq polymerase (ThermoFischer Scientific, Waltham, MA, USA).

Total RNA extracted from Madin-Darby bovine kidney (MDBK) cells infected with BVDV-1 Singer (cp), BVDV-2 890 (ncp), HoBi-like virus LV04/12 (Silveira et al. 2017) were used as controls. Ultrapure water was used as negative control. Pestivirus-free MDBK cells were grown in minimal essential medium (MEM) with $10 \%$ equine serum and supplemented with antibiotics. The sensitivity of each PCR was determining by performing 10 -fold dilutions of supernatants of MDBK cells infected with each control virus, followed by RNA extraction, cDNA synthesis and PCR as described above. PCR products were resolved in a $1.5 \%$ agarose gel stained by Gel Red ${ }^{\circledR}$ (Biotium, Hayward, CA, USA) and visualized under UV light after electrophoresis (60V, $40 \mathrm{~min}$ ). For nucleotide sequencing, PCR products were purified using PureLink ${ }^{\circledR}$ Quick Gel Extraction and PCR Purification Combo Kit (Life Technologies, Carlsbad, CA). Positive samples were sequenced in duplicates using the BigDye kit. The sequences were analyzed by Staden program (Staden 1996) to obtain the consensus sequence. The alignment of the sequences with sequences deposited in GenBank was performed using the program BioEdit Sequence Alignment Editor Software suite, version 7.0.5.3 (http://www.mbio.ncsu.edu/bioedit/bioedit.html). The phylogenetic analysis was conducted in the Molecular Evolutionary Genetics Analysis (MEGA) software 5.0 (Tamura et al. 2011), using the Neighbor-joining method, and the evolutionary distances were computed using the $p$-distance method. The bootstrap values were calculated using 1000 replicates.

FBS samples were also submitted to virus isolation in MDBK cells using standard protocols (Botton et al. 1998). Briefly, 100uL of FBS was added to the culture medium of MDBK cell monolayers grown in 6-well plates and submitted to three passages of five days each, followed by detection of viral antigens by fluorescent antibody assay (FA) at the end of the third passage.

\section{RESULTS AND DISCUSSION}

Thirty-nine FBS lots (53.4\%) were found contaminated with RNA of at least one pestivirus species by the PCRs targeting the 5'UTR (Tables 1 and 2). The first PCR using the panpestivirus primers HCV90-368 (Ridpath \& Bolin 1998) resulted in $35 / 73$ positive samples (47.9\%). Nucleotide sequencing of the amplicons revealed 34 samples harboring BVDV-1 (23 BVDV-1a, 8 BVDV-1b and 3 BVDV-1d) and one containing HoBi-like virus. The amplification of a HoBi-like virus out of one batch indicates a high level of contamination since these primers were shown to poorly amplify HoBi-like viruses (Bauermann et al. 2013). In any case, these results indicate the predominance of BVDV-1 among the viruses detected in the examined samples $(35 / 45,77.7 \%)$.

The lack of amplification of BVDV-2 by primers HCV90-368 was somehow surprising due to the wide circulation of this virus among Brazilian cattle (Cortez et al. 2006, Bianchi et al. 2011, Silveira et al. 2017). Then, a second primer set was designed to specifically amplify BVDV-2, either as a sole virus or in mixed contamination (Table 1). These primers were shown to amplify specifically BVDV-2 (at little as 10 genome copies), even in mixtures containing BVDV-1 in 100 -fold higher amounts (not shown). The PCR using this set of primers resulted in the positive amplification in six batches, all confirmed as BVDV-2 by nucleotide sequencing ( 2 BVDV-2a; 3 BVDV-2b and one undetermined). Three of these samples also contained BVDV-1 (detected by the HCV90-368 PCR) and one contained BVDV-2 plus HoBilike virus (detected by the HoBi-virus-specific PCR). Thus, BVDV-2 accounted for $13.6 \%(6 / 44)$ of the pestiviruses detected in Brazilian FBS batches.

The third PCR used primers specific for HoBi-like virus (N2-R5) and yielded four positive samples, one was the same sample detected by primers HCV90-368. The identity of $\mathrm{HoBi}$-like viruses was confirmed by nucleotide sequencing. The presence of other pestiviruses in the samples seemed not to affect amplification of HoBi-like by this set of primers. Thus, HoBi-like viruses comprised $8.9 \%$ $(4 / 44)$ of the pestiviruses contaminating FBS batches. Five FBS batches contained more than one viral species (3 were positive for BVDV-1 and BVDV-2; and one each contained HoBi-like virus and BVDV-1 or BVDV-2).

The obtained sequences were submitted to identity matrix based on the 5' UTR. The nucleotide identity among the BVDV-1a ranged from 90.8 to $98.7 \%$; BVDV-1b, 93.9 to $96.7 \%$; BVDV-1d, 96.2 to $97.6 \%$. The 5' UTR identity among BVDV-2 ranged from $90.3 \%$ to $100 \%$ and among HoBi-like viruses varied from 98.3 to $100 \%$. Figure 1 depicts the phylogenetic relationships among the detected pestiviruses.

A number of studies have demonstrated pestivirus contamination of FBS originated from Brazil and other South American countries (Liu et al. 2009, Xia et al. 2013, Peletto et al. 2012, Giammarioli et al. 2015). Our study reinforced these findings, detecting $53.4 \%$ batches containing pestivirus RNA. Although only one lot contained infectious virus, the high frequency of pestivirus RNA contamination should call attention to the FBS manufacturers and regulatory agencies for the need of continuous monitoring and strict application and use of updated procedures for pestivirus detection.

Contamination of FBS with pestiviruses may have important consequences, including contamination of human and veterinary vaccines (Falcone et al. 1999) and interference with virology diagnosis and research (Stahl et al. 2007). Widespread distribution of FBS may also represent a means for introduction of contaminating viruses into free countries (Stahl et al. 2007, Bauermann et al. 2013, Giammarioli et al. 2015).

In general, these results reflect the distribution and frequency of BVDV genotypes and HoBi-like viruses in Brazil reported in previous studies (Cortez et al. 2006, Bianchi et al. 2011, Silveira et al. 2017). The low frequency of BVDV-2 detection contrasts with a highest frequency detected previously, yet it might be partially explained by the preferential amplification of BVDV-1 sequences by the pestivirus primers used in the initial reactions. On the other hand, the frequency of HoBi-like virus detection confirms the wide and frequent distribution of this novel group of pestiviruses among Brazilian cattle (Cortez et al. 2006, Bianchi et al. 2011, Silveira et al. 2017). 


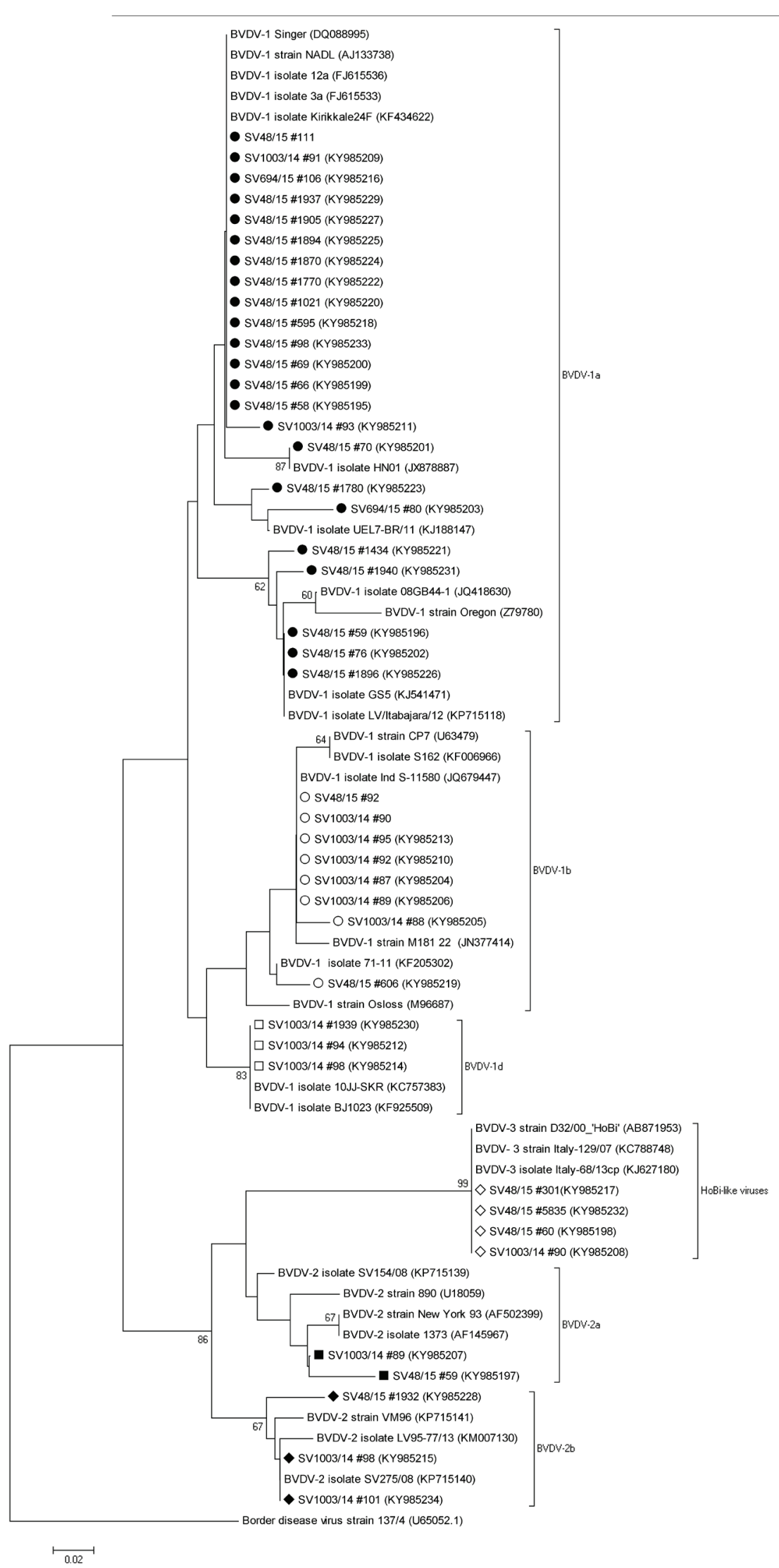

Fig.1. Phylogenetic tree based on the 5'UTR region of the pestivirus genome. The tree was built using the Neighbor-joining method and the evolutionary distances were computed using the $p$-distance method. The bootstrap values were calculated using 1000 replicates. The identified viruses are indicated by diamonds, circles or boxes. 
Table 2. Detection of pestiviruses by RT-PCR in Brazilian lots of FBS collected from 2006 to 2014

\begin{tabular}{|c|c|c|c|c|c|c|}
\hline \multirow{2}{*}{ SV Identification } & \multirow{2}{*}{ Origin identification } & \multirow{2}{*}{ Status ${ }^{\mathrm{a}}$} & \multirow{2}{*}{ Year $^{\mathrm{b}}$} & \multicolumn{3}{|c|}{ Primers $^{\mathrm{c}}$} \\
\hline & & & & HCV90-368 & BVDV-2 2F-2R & N2-R5 \\
\hline SV48/15 \#66 & IB-66 & Pooled & 2006 & $B V D V-1 a^{d}$ & - & - \\
\hline SV48/15 \#70 & IB-70 & Pooled & 2006 & BVDV-1a & - & - \\
\hline SV48/15 \#60 & IB-60 & Pooled & 2006 & - & BVDV-2* & HoBi-like \\
\hline SV48/15 \#59 & IB-59 & Pooled & 2007 & BVDV-1a & BVDV-2a & - \\
\hline SV48/15 \#76 & IB-76 & Pooled & 2007 & BVDV-1a & - & - \\
\hline SV48/15 \#111 & IB-111 & Pooled & 2007 & BVDV-1a & - & - \\
\hline SV48/15 \#58 & IB-58 & Pooled & 2007 & BVDV-1a & - & - \\
\hline SV48/15 \#69 & IB-69 & Pooled & 2007 & BVDV-1a & - & - \\
\hline SV48/15 \#98 & IB-98 & Pooled & 2008 & BVDV-1a & - & - \\
\hline SV 48/15 \#92 & IB-92 & Pooled & 2008 & BVDV-1b & - & - \\
\hline SV48/15 \#1021 & IB-1021 & Pooled & 2009 & BVDV-1a & - & - \\
\hline SV1003/14 \#89 & IN-89 & Packed & 2009 & BVDV-1b & BVDV-2a & - \\
\hline SV48/15 \#1434 & IB-1434 & Pooled & 2010 & BVDV-1a & - & - \\
\hline SV48/15 \#595 & IB-595 & Pooled & 2010 & BVDV-1a & - & - \\
\hline SV48/15 \#606 & IB-606 & Pooled & 2010 & BVDV-1b & - & - \\
\hline SV48/15 \#1937 & IB-1937 & Pooled & 2010 & BVDV-1a & - & - \\
\hline SV48/15 \#1780 & IB-1780 & Pooled & 2011 & BVDV-1a & - & - \\
\hline SV48/15 \#1770 & IB-1770 & Pooled & 2011 & BVDV-1a & - & - \\
\hline SV1003/14 \#92 & IN-92 & Packed & 2011 & BVDV-1b & - & - \\
\hline SV1003/14 \#93 & IN-93 & Packed & 2011 & BVDV-1a & - & - \\
\hline SV48/15 \#5835 & IB-5835 & Pooled & 2011 & HoBi-like & - & HoBi-like \\
\hline SV1003/14 \#87 & IN-87 & Packed & 2012 & BVDV-1b & - & - \\
\hline SV1003/14 \#95 & IN-95 & Packed & 2013 & BVDV-1b & - & - \\
\hline SV1003/14 \#98 & IN-98 & Packed & 2013 & BVDV-1d & BVDV-2b & - \\
\hline SV1003/14 \#90 & IN-90 & Packed & 2014 & BVDV-1b & - & HoBi-like \\
\hline SV1003/14 \#91 & IN-91 & Packed & 2014 & BVDV-1a & - & - \\
\hline SV694/15 \#80 & IN-80 & Packed & 2014 & BVDV-1a & - & - \\
\hline SV694/15 \#106 & IN-106 & Packed & 2014 & BVDV-1a & & \\
\hline SV48/15 \#1940 & IB-1940 & Pooled & $\mathrm{NI}^{\mathrm{e}}$ & BVDV-1a & - & - \\
\hline SV48/15 \#301 & IB-301 & Pooled & $\mathrm{NI}$ & - & - & HoBi-like \\
\hline SV48/15 \#1905 & IB-1905 & Pooled & NI & BVDV-1a & - & - \\
\hline SV1003/14 \#1939 & IB-1939 & Pooled & NI & BVDV-1d & - & - \\
\hline SV1003/14 \#1870 & IB-1870 & Pooled & NI & BVDV-1a & - & - \\
\hline SV48/15 \#1896 & IB-1896 & Pooled & NI & BVDV-1a & & \\
\hline SV48/15 \#1894 & IB-1894 & Pooled & $\mathrm{NI}$ & BVDV-1a & - & - \\
\hline SV1003/14 \#88 & IN-88 & Packed & NI (valid until 2016) & BVDV-1b & - & - \\
\hline SV1003/14 \#101 & IN-101 & Packed & NI (valid until 2016) & - & BVDV-2b & - \\
\hline SV1003/14 \#94 & IN-94 & Packed & NI (valid until 2019) & BVDV-1d & - & - \\
\hline
\end{tabular}

a Pooled, unpacked FBS sent for pestivirus monitoring (IB - Instituto Biológico de São Paulo); or packed/labeled commercial FBS (Inmetro, RJ), ${ }^{\mathrm{b}}$ Corresponds to the year of collection informed by the supplier/manufacturer, ${ }^{\mathrm{c}}$ Primers HCV90-368 are panpestivirus; primers $2 \mathrm{~F}-2 \mathrm{R}$ were designed to amplify exclusively BVDV-2; primers N2-R5 are specific for HoBi-like viruses, ${ }^{\mathrm{d}}$ The identity of the respective virus was determined by nucleotide sequencing of the amplicons, ${ }^{\text {e }}$ Date of serum collection not informed; * The BVDV-2 subgenotype could not be determined; this sequence is not shown in the phylogenetic tree.

\section{CONCLUSIONS}

Our results showed a high frequency of pestivirus RNA contamination of FBS produced in Brazil. Interestingly, HoBi-like viruses accounted for approximately $9 \%$ of the pestivirus RNA detected in FBS and were present in 5\% of the lots, confirming the widespread distribution of these viruses in Brazil.

These findings reinforce the need for continuous monitoring and strict application of methods for virus inactivation as to provide a safe product for the industry and research.
Acknowledgements.- F.L. Monteiro, J.F. Cargnelutti, E.F. Flores, and R. Weiblen recipients of fellowships of the Conselho Nacional de Desenvolvimento Científico e Tecnológico (CNPq) research fellows. We thank Fernando V. Bauermann for the valuable help and advices during the elaboration of the manuscript.

\section{REFERENCES}

Bauermann F.V. \& Ridpath J.F. 2015. HoBi-like viruses, the typical atypical bovine pestivirus. Anim. Health Res. Rev. 16(1):64-69. http://dx.doi. org/10.1017/S146625231500002X. PMid:26050574. 
Bauermann F.V., Flores E.F., Falkenberg S.M., Weiblen R. \& Ridpath J.F. 2014 Lack of evidence for the presence of emerging HoBi-like viruses in North American fetal bovine serum lots. J. Vet. Diagn. Invest. 26(1):10-17. http:// dx.doi.org/10.1177/1040638713518208. PMid:24415196.

Bauermann F.V., Ridpath J.F., Weiblen R. \& Flores E.F. 2013. HoBi-like viruses: an emerging group of pestiviruses. J. Vet. Diagn. Invest. 25(1):6-15. http:// dx.doi.org/10.1177/1040638712473103. PMid:23345268.

Becher P., Orlich M., Shannon A.D., Horner G., K $\sqrt{\partial}$ nig M. \& Thiel H.J. 1997. Phylogenetic analysis of pestiviruses from domestic and wild ruminants. J. Gen. Virol. 78(Pt 6):1357-1366. http://dx.doi.org/10.1099/0022-131778-6-1357. PMid:9191930.

Bianchi E., Martins M., Weiblen R. \& Flores E.F. 2011. Genotypic and antigenic profile of bovine viral diarrhea virus isolates from Rio Grande do Sul, Brazil (2000-2010). Pesq. Vet. Bras. 31:649-655. http://dx.doi.org/10.1590/ S0100-736X2011000800003.

Botton S.A., Gil L.H.V.G., Silva A.M., Flores E.F., Weiblen R., Pituco E.M., Roehe P.M., Moojen V. \& Wendelstein A.C. 1998. Caracterização preliminar de amostras do vírus da Diarréia Viral Bovina (BVDV) isoladas no Brasil. Pesq. Vet. Bras. 18(2):84-92. http://dx.doi.org/10.1590/S0100-736X1998000200008.

Cortez A., Heinemann M.B., Castro A.M., Soares R.M., Pinto A.M., Alfieri A.A., Flores E.F., Leite R.C. \& Richtzenhain L.J. 2006. Genetic characterization of Brazilian bovine viral diarrhea virus isolates by partial nucleotide sequencing of the 50-UTR region. Pesq. Vet. Bras. 26(4):211-216. http:// dx.doi.org/10.1590/S0100-736X2006000400005.

Decaro N., Lucente M.S., Mari V., Cirone F., Cordioli P., Camero M., Sciarretta R., Losurdo M., Lorusso E. \& Buonavoglia C. 2011. Atypical pestivirus and severe respiratory disease in calves, Europe. Emerg. Infect. Dis. 17(8):15491552. http://dx.doi.org/10.3201/eid1708.101447. PMid:21801648.

Decaro N., Lucente M.S., Mari V., Sciarretta R., Pinto P., Buonavoglia D., Martella V. \& Buonavoglia C. 2012. HoBi-like pestivirus in aborted bovine fetuses. J. Clin. Microbiol. 50(2):509-512.http://dx.doi.org/10.1128/JCM.0588711. PMid:22162547.

Falcone E., Tollis M. \& Conti G. 1999. Bovine viral diarrhea disease associated with a contaminated vaccine. Vaccine 18(5/6):387-388. PMid:10636817.

Giammarioli M., Ceglie L., Rossi E., Bazzucchi M., Casciari C., Petrini S. \& De Mia G.M. 2015. Increased genetic diversity of BVDV-1: recent findings and implications thereof. Virus Genes 50(1):147-151. http://dx.doi. org/10.1007/s11262-014-1132-2. PMid:25349062.

Liu L., Kampa J., Belak S. \& Baule C. 2009. Virus recovery and full-length sequence analysis of the atypical bovine pestivirus Th/04_KhonKaen. Vet. Microbiol.138(1/2):62-68. http://dx.doi.org/10.1016/j.vetmic.2009.03.006. PMid:19349128.

Mishra N., Rajukumar K., Pateriya A., Kumar M., Dubey P., Behera S.P., Verma A., Bhardwaj P., Kulkarni D.D., Vijaykrishna D. \& Reddy N.D. 2014. Identification and molecular characterization of novel and divergent $\mathrm{HoBi}$-like pestiviruses from naturally infected cattle in India. Vet. Microbiol. 174(1/2):239-246. http://dx.doi.org/10.1016/j.vetmic.2014.09.017. PMid:25301283.

Peletto S., Zuccon F., Pitti M., Gobbi E., Marco L.D., Caramelli M., Masoero L. \& Acutis P.L. 2012. Detection and phylogenetic analysis of an atypical pestivirus, strain IZSPLV_To. Res. Vet. Sci. 92(1):147-150. http://dx.doi. org/10.1016/j.rvsc.2010.10.015. PMid:21093884.

Ridpath J.F. \& Bolin S.R. 1998. Differentiation of types 1a, 1 b and 2 bovine viral diarrhea virus (BVDV) by PCR. Mol. Cell. Probes 12(2):101-106. http://dx.doi.org/10.1006/mcpr.1998.0158. PMid:9633045.

Ridpath J.F., Bolin S.R. \& Dubovi E.J. 1994. Segregation of bovine viral diarrhea virus into genotypes. Virology 205(1):66-74. http://dx.doi.org/10.1006/ viro.1994.1620. PMid:7975238.

Schirrmeier H., Strebelow G., Depner K., Hoffmann B. \& Beer M. 2004. Genetic and antigenic characterization of an atypical pestivirus isolate, a putative member of a novel pestivirus species. J. Gen. Virol. 85(Pt 12):3647-3652. http://dx.doi.org/10.1099/vir.0.80238-0. PMid:15557237.

Silveira S., Weber M.N., Mósena A.C., da Silva M.S., Streck A.F., Pescador C.A., Flores E.F., Weiblen R., Driemeier D., Ridpath J.F. \& Canal C.W. 2017. Genetic diversity of Brazilian bovine pestiviruses detected between 1995 and 2014. Transbound. Emerg. Dis. 64(2):613-623. http://dx.doi.org/10.1111/ tbed.12427. PMid:26415862.

Staden R. 1996. The Staden sequence analysis package. Mol. Biotechnol. 5(3):233-241. http://dx.doi.org/10.1007/BF02900361. PMid:8837029.

Ståhl K., Kampa J., Alenius S., Wadman A.P., Baule C., Aiumlamai S. \& Belák S. 2007. Natural infection of cattle with an atypical 'HoBi'-like Pestivirus: implications for BVD control and for the safety of biological products. Vet. Res. 38(3):517-523. http://dx.doi.org/10.1051/vetres:2007012. PMid:17506974.

Tamura K., Peterson D., Peterson N., Stecher G., Nei M. \& Kumar S. 2011. MEGA5: molecular evolutionary genetics analysis using maximum likelihood, evolutionary distance, and maximum parsimony methods. Mol. Biol. Evol. 28(10):2731-2739. http://dx.doi.org/10.1093/molbev/ msr121. PMid:21546353.

Vilcek S., Paton D.J., Durkovic B., Strojny L., Ibata G., Moussa A., Loitsch A., Rossmanith W., Vega S., Scicluna M.T. \& Paifi V. 2001. Bovine viral diarrhea virus genotype 1 can be separated into at least eleven genetic groups. Arch.Virol. 146(1):99-115. http://dx.doi.org/10.1007/s007050170194. PMid:11266221.

Xia H., Larska M., Giammarioli M., De Mia G.M., Cardeti G., Zhou W., Alenius S., Belák S. \& Liu L. 2013. Genetic detection and characterization of atypical bovine pestiviruses in foetal bovine sera claimed to be of Australian origin. Transbound. Emerg. Dis. 60(3):284-288. http://dx.doi.org/10.1111/j.18651682.2012.01341.x. PMid:22591445. 